DOI: 10.35757/RPN.2011.19.06

Joanna Szymoniczek

\title{
MIĘDZYNARODOWA \\ POMOC HUMANITARNA I ROZWOJOWA JAKO INSTRUMENTY NIEMIECKIEJ POLITYKI ZAGRANICZNEJ
}

Trzęsienie ziemi na Haiti w styczniu 2010 roku zabiło ponad 230 tys. osób, 26 grudnia 2004 roku w następstwie tsunami spowodowanego przez trzęsienie ziemi życie straciło blisko 300 tys. osób w dwunastu państwach Azji Południowo-Wschodniej, trwająca w latach 2000-2004 susza dotknęła 17 mln ludzi w Etiopii, Erytrei i Somalii; w krajach tych ponad $50 \%$ dzieci jest chronicznie niedożywionych, a ponad $10 \%$ cierpi na ostry deficyt żywności; na świecie w ciągu ostatnich dwóch dekad ponad 2 mln dzieci zmarło w rezultacie konfliktu zbrojnego, a ponad trzykrotnie więcej zostało trwale okaleczonych ${ }^{1}$. Codziennie świat obiegają informacje o klęskach, katastrofach czy konfliktach niosących ze sobą kolejne ofiary. Udzielenie im pomocy to ludzki odruch związany z uczuciem litości, chęcią wsparcia, stanowiący przejaw humanitaryzmu, wyraz ludzkiej empatii i solidarności. Dotyczy to zwłaszcza spektakularnych, tragicznych w skutkach klęsk i katastrof, które poprzez swoją "atrakcyjność" i obecność w mediach są w stanie zmobilizować społeczność międzynarodową do podjęcia działań, mających na celu udzielenie pomocy poszkodowanym².

1 G. Michałowska: Pomoc humanitarna Organizacji Narodów Zjednoczonych, w: Organizacja Narodów Zjednoczonych. Bilans i perspektywy, red. J. Symonides, Warszawa 2006, s. 323-324, 328.

2 M. Marczyński: Europejska pomoc humanitarna, http://www.pomagamy.pl, dostęp 18 marca 2010 roku. 
W przypadku zaistnienia katastrofy, klęski bądź konfliktu zbrojnego udziela się pomocy humanitarnej (zwłaszcza jeśli stosowne władze nie moga nie są w stanie lub nie chcą takiej pomocy udzielić), będącej pomocą doraźna, zaspokajającą najbardziej podstawowe potrzeby, pomagającej zachować życie i godność ofiar sytuacji nadzwyczajnych ${ }^{3}$. Natomiast państwa słabiej rozwinięte mogą liczyć na pomoc rozwojową, którą świadczą państwa oraz organizacje międzynarodowe $\mathrm{w}$ formie finansowej, materialnej, technicznej i doradczej, mając na celu redukcję ubóstwa, promocję zrównoważonego rozwoju, wsparcie reform demokratycznych i rządów prawa, przestrzeganie praw człowieka, rozwój społeczeństwa obywatelskiego, wspieranie wzrostu gospodarczego, zapobieganie konfliktom oraz promocję bezpieczeństwa globalnego ${ }^{4}$.

Udzielanie pomocy humanitarnej i rozwojowej ma szczególne znaczenie dla państw, które pozostają obok organizacji międzynarodowych - rządowych i pozarządowych - głównymi donatorami pomocy. Jest to bowiem ważny element ich polityki zagranicznej służący przede wszystkim realizacji własnych celów politycznych i ekonomicznych, pozwalający budować korzystny wizerunek na arenie międzynarodowej, mający wpływ na dobre relacje sąsiedzkie i regionalne, pomagający wzmacniać pokój i stabilizację na świecie. Nie oznacza to oczywiście, że za tymi działaniami nie stoją względy humanitarne. Zazwyczaj jednak motywacja takich działań jest podwójna: z jednej strony solidarność i chęć niesienia pomocy, z drugiej - wymierne korzyści, jakie może przynieść podjęcie takiej działalności ${ }^{5}$.

Jednym z głównych donatorów, zarówno jeśli chodzi o pomoc humanitarna, jak i rozwojową są Niemcy. Zaangażowanie się $\mathrm{w}$ taką działalność ma służyć przede wszystkim budowaniu silnej pozycji

${ }^{3}$ G. Michałowska: op. cit., s. 316.

4 P. Bagiński, M. Kowalska: Finansowanie rozwoju krajów słabiej rozwiniętych jako element polityki zagranicznej państw rozwiniętych, w: Pomoc rozwojowa dla krajów rozwijajacych się na przetomie XX i XXI wieku, red. nauk. E. Latoszek, Warszawa 2010, s. 90. Zgodnie z definicją OECD Oficjalna Pomoc Rozwojowa (ang. Official Development Assistance, ODA) to darowizny i pożyczki przekazywane krajom rozwijającym się przez oficjalne instytucje rządowe państw-dawców pomocy lub organizacje międzynarodowe, mające na celu wsparcie rozwoju gospodarczego i dobrobytu w tych krajach. Pożyczki są zaliczane do Oficjalnej Pomocy Rozwojowej. jeśli zawierają element darowizny o wartości co najmniej $25 \%$ wartości pomocy.

${ }_{5}$ M. Marczyński: op. cit., s. 4. 
Niemiec na arenie międzynarodowej, tworzeniu pozytywnego obrazu niemieckiej obecności poza granicami ich kraju (zwłaszcza że wciąż żywe są skojarzenia Niemiec z II wojną światową), uzyskanie wpływu na kształtowanie określonego światopoglądu, postaw społecznych, obyczajowych i politycznych u społeczeństw państw-biorców pomocy, osiąganie konkretnych korzyści finansowych, politycznych i ekonomicznych ${ }^{6}$. Szczególne zaangażowanie Niemiec można było zaobserwować na początku lat pięćdziesiątych ${ }^{7}$, kiedy RFN starała się odbudować swoją pozycję i opinię zniweczoną przez II wojnę światową oraz na początku lat dziewięćdziesiątych, kiedy to zjednoczone już Niemcy starały

6 J. Dobrowolska-Polak: Niemiecka polityka działań humanitarnych, Poznań 2008, s. 7; G. Erler: Mission Weltfrieden. Deutschlands neue Rolle in der Weltpolitik, Freiburg im Breisgau 2009, s. 25-28; A. Nowak: Polityka RFN na rzecz rozwoju krajów Trzeciego Świata (Entwicklungspolitik), Wrocław 1997, s. 18.

7 RFN zaangażowała się $\mathrm{w}$ pomoc rozwojową w chwili rozpadu systemu kolonialnego, czyli na początku lat pięćdziesiątych XX wieku. Jako krajowi z minimalną przeszłością kolonialną udało się nawiązać kontakty z państwami Trzeciego Świata, oparte, zwłaszcza w Ameryce Łacińskiej, na wcześniejszych doświadczeniach i emigracji z Niemiec. Działalność rozwojowa miała służyć przede wszystkim realizacji doktryny Hallsteina (co nie było łatwe, bowiem część państw żądała od Niemiec większej pomocy, grożąc uznaniem NRD), odbudowie pozycji i opinii na arenie międzynarodowej, a także stanowiła część zachodnich działań mających na celu zahamowanie ekspansji komunizmu w krajach Trzeciego Świata. W ciągu pierwszych 20 lat działalności Niemcy udzieliły pomocy rozwojowej 107 państwom, przede wszystkim Indiom, Brazylii, Iranowi, Argentynie, Pakistanowi, Turcji, Meksykowi, Izraelowi i Indonezji, realizując 350 programów rozwojowych w sektorze rolnym, 185 programów rozwoju opieki medycznej, 90 programów budowy sieci radiowo-telewizyjnej. Zmiana nastąpiła po objęciu przez Willy'ego Brandta funkcji kanclerza, który doprowadził do przyjęcia programu, zgodnego z zaleceniami ONZ i oczekiwaniami państw Trzeciego Świata, zakładającego międzynarodową współpracę na rzecz rozwoju, jako priorytety zachodnioniemieckiej polityki rozwoju. Oznaczało to rezygnację z silnych uwarunkowań politycznych, które przez 20 lat determinowały jej kształt, nie oznaczało jednak rezygnacji RFN z realizacji własnych interesów politycznych i ekonomicznych. Rozwiązanie to nie utrzymało się długo, bowiem nowy rząd z Helmutem Schmidtem na czele powrócił do silniejszego powiązania polityki rozwojowej z zagranicznymi interesami gospodarczymi, co miało służyć bezpieczeństwu surowcowemu RFN. Pomoc rozwojowa została zwiększona, jednak znaczna cześć świadczeń kapitałowych miała charakter wiązany. Rząd Helmuta Kohla, ze względu na międzynarodową sytuację polityczną, zaczął traktować pomoc rozwojową jako element przeciwstawiania się wpływom komunistycznym w krajach Trzeciego Świata, co oznaczało wzrost poparcia dla krajów o prozachodniej orientacji politycznej, ustrojowej i gospodarczej. Za główny cel uznano problemy zadłużenia i klęskę głodu w Afryce, a działania miały być tak skonstruowane, aby wyzwolić aktywność i przedsiębiorczość Afrykanów. Kolejne przedefiniowanie pomocy rozwojowej nastąpiło po zjednoczeniu Niemiec; A. Nowak: op. cit., s. 29-41. 
się zmniejszyć obawy świata i potwierdzić swoją pozycję na arenie międzynarodowej poprzez bardzo aktywne zaangażowanie się w pomoc, przede wszystkim państwom Trzeciego Świata. Nie było to wówczas proste, bowiem konieczność przeznaczania olbrzymich kwot na odbudowę wschodnich landów spowodowała, że środki asygnowane na wiele innych celów, w tym właśnie na pomoc międzynarodową uległy znacznemu zmniejszeniu. Jednak $w$ liczbach bezwzględnych Niemcy pozostały jednym z głównych dostarczycieli pomocy na świecie ${ }^{8}$, przekazując około 2,5-3\% światowej pomocy humanitarnej (średnio rocznie jest to około 200 mln dolarów amerykańskich) i około 0,2-0,4\% własnego PKB na pomoc rozwojową 9 .

Wysokość środków, jakie przeznacza dane państwo na pomoc rozwojowa, wynika ze zobowiązań podjętych podczas 7. Sesji Specjalnej Zgromadzenia Ogólnego ONZ w 1980 roku, które zostały powtórzone w Deklaracji Milenijnej. Dokument ten przyjęty 8 września 2000 roku przez Organizację Narodów Zjednoczonych określa cele społeczności międzynarodowej na pierwszych piętnaście lat XXI wieku: likwidacja skrajnej biedy i głodu, powszechny dostęp do edukacji, równouprawnienie płci i przestrzeganie praw kobiet, zmniejszenie śmiertelności dzieci, zapewnienie zdrowia matek, zwalczanie chorób, przede wszystkim HIV/AIDS i malarii, ochrona środowiska i globalne partnerstwo dla rozwoju ${ }^{10}$. Aby je osiągnąć, najbogatsze i najbardziej rozwinięte państwa świataa ${ }^{11}$, sku-

8 R. Woś: Dyplomacja RFN w kontekście polityki zagranicznej. Między kontynuacja a zmiana, „Biuletyn Niemiecki” 2010, nr 5, s. 5.

9 Bericht der Bundesregierung uber die deutsche humanitäre Hilfe im Ausland 2006 bis 2009, s. 86; Development Aid: Net Official Development Assistance (ODA), http://dx.doi. org/10.1787/20743866-2010-table1, dostęp 21 styczni 2011 r.; G. Erler: op. cit., s. 101.

${ }^{10}$ L. Kasprzyk: op. cit., s. 257-260; D. Heidrich-Hamera, A. Jarczewska-Romaniuk: ONZ wobec ekonomicznych i społecznych wyzwań globalnych, w: Organizacja Narodów Zjednoczonych..., s. 530-533.

${ }^{11}$ Przy ustalaniu poziomu rozwoju zazwyczaj bierze się pod uwagę tzw. Wskaźnik Rozwoju Społecznego (Human Development Index - HDI, wskaźnik socjoekonomicznego rozwoju kraju; składa się on z trzech komponentów: długości życia, poziomu edukacji mierzonego poziomem analfabetyzmu i średnią czasu edukacji oraz dochodu na głowę mieszkańca skorygowanego o lokalne koszty życia) lub Wskaźnik Ubóstwa Społecznego (Human Poverty Index - HPI), który uwzględnia prawdopodobieństwo śmierci przed 60 rokiem życia, procent funkcjonalnych analfabetów, długotrwałe bezrobocie i odsetek ludności uzyskujący poniżej 50\% mediany dochodów, uważając je za bardziej miarodajne niż system oparty tylko na dochodzie narodowym, J. Sachs: Koniec z nędza. Zadanie dla naszego pokolenia, Warszawa 2002, s. 35-39. 
pione w DAC OECD ${ }^{12}$, zobowiązały się do przeznaczania 0,7\% własnego $\mathrm{PKB}^{13}$. Od początku jednak $\mathrm{z}$ egzekwowaniem tej płatności były problemy, które nasiliły się w chwili wybuchu kryzysu finansowego. Tylko Dania, Finlandia, Norwegia i Szwecja wywiązują się z tego zobowiązania, dostarczając około $20 \%$ całościowej pomocy rozwojowej. Średnia dla pozostałych państw wynosi około 0,3\% $\mathrm{PKB}^{14}$. Niemcy, choć nie przeznaczają środków w wysokości tego zobowiązania, pozostają jednak głównym donatorem na świecie, zwłaszcza w liczbach bezwzględnych, mając świadomość, jak nieprzestrzeganie przyjętych zobowiązań będzie rzutować na ich wizerunek, zwłaszcza w krajach Trzeciego Świata, ale też chcąc uzyskać dodatkowy argument w budowaniu swojej pozycji na arenie międzynarodowej.

Wysokość środków przeznaczanych przez państwa na pomoc humanitarną nie wynika natomiast ze zobowiązań międzynarodowych. Jest po części wprawdzie finansowana ze składek członkowskich (te często są ściśle określone) organizacji międzynarodowych, które zajmują się taką formą działalności. W większości jednak środki na nią pochodzą z dobrowolnych wpłat, które zbierane są na aktualne potrzeby humanitarne bądź przekazywane są $w$ ramach pomocy bilateralnej. Jednak sam obowiązek niesienia pomocy humanitarnej wynika z artykułu 1 punktu 3 Karty Narodów Zjednoczonych, który nakazuje państwom członkowskim „rozwiązywać w drodze współpracy międzynarodowej zagadnienia międzynarodowe o charakterze gospodarczym, społecznym i kulturalnym lub humanitarnym, jak również popierać i zachęcać do poszanowania praw człowieka i podstawowych wolności dla wszystkich bez względu na różnice rasy, płci, języka lub wyznania".

${ }^{12}$ Komitet Pomocy Rozwojowej Organizacji Współpracy Gospodarczej i Rozwoju (Decelopment Assistance Committee - DAC OECD) jest organem OECD koordynującym pomoc udzielaną przez najbardziej rozwinięte państwa członkowskie Organizacji krajom rozwijającym się i państwom w okresie transformacji, a także forum współpracy na rzecz zwiększenia efektywności działań pomocowych oraz ustalania zasad przekazywania pomocy rozwojowej. Obecnie członkami DAC są 22 państwa członkowskie OECD oraz Komisja Europejska.

${ }^{13}$ Millenniums-Erklärung der Vereinten Nationen, verabschiedet von der Generalversammlung der Vereinten Nationen zum Abschluss des vom 6.-8 September 2000 abgehaltenen Mileniumsgipfels in New York, Deutsche Entwicklungspolitik auf einen Blick, Berlin 2010, s. 3.

${ }^{14}$ L. Kasprzyk: Rozwój ekonomiczny - nadzieją na wyrównanie szans, w: Organizacja Narodów Zjednoczonych..., s. 249; P. Ogonowski: Wyzwania rozwojowe, w: ibidem, s. 511-512, 520. 
Rozwinięcie tego obowiązku nastąpiło w Deklaracji o prawach i obowiązkach jednostek, grup i organów społecznych odnośnie do promocji i ochrony uniwersalnych praw człowieka i podstawowych wolności, przyjętej przez Zgromadzenie Ogólne Narodów Zjednoczonych 9 grudnia 1998 roku. Natomiast obowiązek pomagania w warunkach konfliktu zbrojnego wynika z konwencji genewskich z 1949 roku (zwłaszcza artykuły 47-78 IV konwencji genewskiej) wraz z pierwszym protokołem dodatkowym ${ }^{15}$, w których znalazły się następujące zapisy: „Jeżeli ludność terytorium okupowanego lub część tej ludności jest niedostatecznie zaopatrzona, Mocarstwo okupacyjne zgodzi się na przeprowadzenie akcji pomocy na rzecz tej ludności i ułatwi tę akcję w miarę wszystkich swoich możliwości. Akcje te, które mogą być podejmowane przez Państwo lub przez bezstronne organizacje humanitarne, jak Międzynarodowy Komitet Czerwonego Krzyża, polegać będą zwłaszcza na przesyłaniu żywności, środków leczniczych i odzieży".

Udzielanie pomocy może następować $\mathrm{w}$ ramach pomocy dwustronnej (państwo-biorca i państwo-donator), trójstronnej (państwo biorca i dwa państwa-donatorzy) i wielostronnej (głównie poprzez organizacje międzynarodowe). Ta ostatnia preferowana jest przez państwa-biorców. Nie uzależnia ona bowiem od konkretnego dawcy, jest bardziej efektywna ze względu na to, że organizacje międzynarodowe mają dużo większe możliwości rozpoznania potrzeb i priorytetów rozwojowych całych regionów i poszczególnych krajów. Organizacje posiadają też sprawne i doświadczone technicznie systemy koordynacji i transferu środków pomocy. Poza tym wiele przedsięwzięć rozwojowych prowadzonych w krajach Trzeciego Świata przekracza możliwości finansowe, techniczne i organizacyjne pojedynczego kraju. Stąd jedno z największych znaczeń dla pomocy humanitarnej ma system zintegrowanych apeli humanitarnych (system Consolidated Appeal Process - CAP) ogłaszany wspólnie przez największe międzynarodowe organizacje zajmujące się udzielaniem i koordynowaniem działań związanych z pomocą humanitarną. Tymczasem Niemcy rzadko i niechętnie przekazują fundusze $\mathrm{w}$ ramach inicjatyw międzynaro-

${ }^{15}$ M. Marczyński: op. cit., s. 2; teksty dokumentów: M. Flemming: Międzynarodowe prawo humanitarne konfliktów zbrojnych. Zbiór dokumentów, uzup. i red. M. Gąska, E. Mikos-Skuza, Warszawa 2003. 
dowych, zwłaszcza mających na celu skupienie środków finansowych „na wszelki wypadek” przed zaistnieniem katastrofy humanitarnej. Łącznie przekazują w ten sposób tylko 35\% środków przekazywanych na pomoc wobec średnio $70 \%$ przekazywanych przez inne państwa. Tak niski udział w pomocy wielostronnej, poza RFN, ma tylko Arabia Saudyjska ${ }^{16}$.

Przekazywanie środków przede wszystkim w ramach pomocy bilateralnej pozwala Niemcom na działanie $\mathrm{w}$ wybranym regionie świata, nie tylko zgodnie z potrzebami, ale przede wszystkim zgodnie z założeniami własnej polityki zagranicznej. Widać to przede wszystkim w geograficznym podziale środków niemieckich. W ostatnich latach średnio $41 \%$ środków na pomoc zostało przeznaczone na rzecz Afryki, choć zdecydowanie więcej potrzeb humanitarnych wynikających z klęsk żywiołowych i konfliktów zbrojnych skumulowanych było w Azji ${ }^{17}$. Swobodzie wyboru regionu towarzyszy także dowolność wyboru sektora wsparcia. Zgodnie $\mathrm{z}$ materiałami informacyjnymi MSZ sektory pomocy humanitarnej w niemieckiej polityce humanitarnej hierarchizowane są następująco: woda pitna i żywność, pomoc medyczna (transport lekarstw i jednorazowych materiałów medycznych, wyposażenie tymczasowych centrów medycznych), ochrona ludności przed skutkami kryzysów: przekazywanie pozażywnościowej pomocy w postaci ubrań, koców oraz budowa tymczasowych schronień, tworzenie minimalnych warunków bezpieczeństwa dla uchodźców $^{18}$ (grupowanie w obozach, rejestracje i wydawanie dokumentów) ${ }^{19}$.

${ }^{16}$ I. Zawiślińska: Koncepcja rozwoju zrównoważonego - przesłanki powstania i zagrożenia w jej realizacji, w: Pomoc rozwojowa..., s. 61-64.

${ }^{17}$ Humanitarian Aid from the European Community. Emergency Aid, Food Aid, Refugee Aid, Brussel 1992, s. 28-29.

${ }^{18}$ Zainteresowanie Niemiec problemami uchodźców na świecie wynika przede wszystkim z tego, że RFN jest jednym z głównych państw, w którym składane są wnioski o status uchodźcy, choć liczba składanych wniosków azylowych zdecydowanie zmalała w 1996 roku i do dziś spada. Jest to związane przede wszystkim z zakończeniem wojny w byłej Jugosławii. Jednak inne konflikty trwające nieustannie na całym świecie powodują stały napływ uchodźców, mimo to ich liczba nie jest tak duża jak na początku lat dziewięćdziesiątych. RFN wybierają z powodu powiązań historycznych i geograficznej bliskości, głównie obywatele Turcji, Iraku czy byłej Jugosławii. Chcąc zmniejszyć napływ uchodźców, RFN podejmuje działania mające na celu polepszyć los potencjalnych azylantów w ich ojczyznach bądź w krajach trzecich. Jest to zgodne z polityką Unii Europejskiej, dla której pomoc uchodźcom (poza granicami UE) jest jednym z priorytetów działalności humanitarnej (obok pomocy żywnościowej i pomocy w sytuacji klęski i katastrofy).

${ }^{19}$ G. Erler: op. cit., s. 243-248. 
Kolejnym argumentem przemawiającym za pomocą bilateralną jest brak jej anonimowości (czasami jednak może to być wadą). W Afganistanie Niemcy przekazują pomoc za pośrednictwem organizacji posługujących się niemieckobrzmiącymi nazwami, po niemiecku znakowana jest też przekazywana ludności pomoc. Pomoc ta trafia głównie do ludności zamieszkującej północno-wschodnią część tego kraju, a nie północno-zachodnia, która tej pomocy najbardziej potrzebuje. Wiąże się to $\mathrm{z}$ tym, że to właśnie $\mathrm{w}$ północno-wschodnim rejonie stacjonują jednostki Bundeswehry, a pomoc ma służyć zjednywaniu ludności dla działających w Afganistanie niemieckich oddziałów i poprawić bezpieczeństwo żołnierzy. Tymczasem w Iraku, gdzie podtrzymuje się postrzeganie RFN jako państwa niezaangażowanego bezpośrednio w konflikt, przekazuje się pomoc humanitarną za pośrednictwem międzynarodowych organizacji lub organizacji niemieckich stosujących anglojęzyczne nazwy ${ }^{20}$.

$\mathrm{W}$ ramach zaangażowania się $\mathrm{w}$ pomoc wielostronną dla Niemiec najważniejsze znaczenie ma udział w pomocy przekazywanej przez Organizację Narodów Zjednoczonych i Unię Europejską.

Organizacja Narodów Zjednoczonych jest największym donatorem pomocy na świecie. $\mathrm{W}$ ciągu ponad sześćdziesięciu lat działalności wykształciła szczereg rozwiązań, które odpowiadają za działalność pomocową. Za pomoc humanitarną odpowiada Biuro ds. Koordynacji Pomocy Humanitarnej Organizacji Narodów Zjednoczonych (United Nations Office for the Coordination Humanitarian Affairs - OCHA) powstałe w styczniu 1998 roku z przekształcenia utworzonego w 1992 roku Departamentu Pomocy Humanitarnej ${ }^{21}$ oraz wyspecjalizowane agendy ONZ, takie jak Światowa Organizacja Zdrowia (World Health Organization - WHO), Organizacja Narodów Zjednoczonych ds. Wyżywienia i Rolnictwa (Food and Agriculture Organization of the United Nations - FAO), Fundusz Narodów Zjednoczonych na rzecz Dzieci (United Nations International Children's Emergency Fund - UNICEF), Światowy Program Żywnościowy (WFP (World Food Programme - WFP), Urząd Wysokiego Komisarza Narodów Zjednoczonych ds. Uchodźców (United Nations High Commissioner for Refugees - UNHCR). Natomiast za pomoc roz-

\footnotetext{
${ }^{20}$ Ibidem, s. 186-189; J. Dobrowolska-Nowak: op. cit., s. 60-63.

${ }^{21}$ G. Michałowska: op. cit., s. 317.
} 
wojową głównie odpowiedzialna jest wyspecjalizowana agenda Program Narodów Zjednoczonych ds. Rozwoju (United Nations Development Programme - UNDP), a także FAO, WHO, Międzynarodowa Organizacja Pracy (International Labour Organization - ILO), Organizacja Narodów Zjednoczonych ds. Rozwoju Przemysłowego (United Nations Industrial Development Organization - UNIDO), Konferencja Narodów Zjednoczonych ds. Handlu i Rozwoju (United Nations Conference on Trade and Development - UNCTAD) oraz Międzynarodowy Bank Odbudowy i Rozwoju (The International Bank for Reconstruction and Development - IBRD) i Międzynarodowy Fundusz Walutowy (International Monetary Fund - IMF). Współpraca RFN z agendami ONZ wyspecjalizowanymi w pomocy rozwojowej rozpoczęła się jeszcze w latach pięćdziesiątych. Do 1973 roku, kiedy RFN stała się pełnoprawnym członkiem ONZ, kraj ten należał już do wszystkich agend i organizacji stowarzyszonych składających się na system ONZ ${ }^{22}$. Zaangażowanie RFN w pomocy wielostronnej prowadzonej przez ONZ w latach pięćdziesiątych i sześćdziesiątych miało duże znaczenie polityczne dla tego kraju. Uczestnicząc w działalności organizacji systemu ONZ, RFN uzyskiwała wpływ na prowadzoną przez nie politykę. Pozwalało to $\mathrm{w}$ wielu wypadkach na blokowanie dostępu do tych organizacji NRD. Tym samym RFN stawała się jedynym reprezentantem Niemiec na forum ONZ, co odpowiadało podstawowym założeniom zachodnioniemieckiej polityki zagranicznej w tym okresie ${ }^{23}$.

Unia Europejska od momentu swego powstania aktywnie uczestniczyła w międzynarodowej polityce rozwojowej i pomocy dla krajów Trzeciego Świata. Zaangażowanie EWG w pomocy wielostronnej wynika w dużym stopniu z silnych historycznych, kulturowych, ale też politycznych i gospodarczych związków poszczególnych członków EWG z różnymi regionami i krajami Trzeciego Świata. Pomoc EWG dla tych krajów odgrywa bardzo ważną rolę, służy bowiem nie tylko ich postępowi gospodarczemu i społecznemu, ale też ściślej wiąże je z krajami EWG. Zasadnicza część pomocy rozwojowej realizowana jest za pomo-

${ }^{22}$ Np. członkiem FAO RFN została już w 1950 roku, IBRD w 1952 roku, UNDP w 1965 roku, Funduszu Ludnościowego Narodów Zjednoczonych (United Nations Population Fund - UNFPA) w 1969 roku.

${ }^{23}$ S. Bierling: Die Aussenpolitik der Bundesrepublik Deutschland. Normen, Aktuere, Entscheidungen, Munchen-Wien-Oldenbourg 1999, s. 143-149; A. Nowak: op. cit., s. 95-101. 
cą wyspecjalizowanej agendy - Europejskiego Funduszu Rozwoju (European Development Fund - EDF). Organizacją pomocy finansowej zajmuje się natomiast Europejski Bank Rozwoju (European Development Bank - EDB ${ }^{24}$, pomoc humanitarna udzielana jest zaś przez ECHO (The European Community Humanitarian Office), na czele którego stoi Komisarz UE ds. współpracy międzynarodowej, pomocy humanitarnej i reagowania kryzysowego. Działania podejmowane są na podstawie Rozporządzenia Rady Unii Europejskiej z dnia 20 czerwca 1996 roku dotyczącego niesienia pomocy humanitarnej przez UE i obejmują przede wszystkim takie akcje jak:

- ratowanie i ochrona życia w czasie sytuacji krytycznych i bezpośrednio w ich następstwie oraz w czasie klęsk żywiołowych,

- udzielanie koniecznej pomocy i wsparcia ludziom narażonym na długotrwałe kryzysy wynikające w szczególności z wybuchów walk lub wojen,

- przeprowadzanie krótkoterminowych prac związanych z odbudową i rekonstrukcją, szczególnie w zakresie infrastruktury i sprzętu [...],

- pokonywanie trudności związanych z konsekwencjami migracji ludności (uchodźcy, przesiedleńcy, migranci),

- zapewnienie przygotowania się na ryzyko klęski żywiołowej ${ }^{25}$.

Wszystkie te instytucje i działania są finansowane przez państwa członkowskie UE, przede wszystkim zaś przez Francję i Niemcy i to mimo tego, że Niemcy niechętnie angażują się w pomoc wielostronną. Jednak wysokość środków niemieckich przeznaczanych na wsparcie innych jest tak wysoka (zwłaszcza w liczbach bezwzględnych), że nawet ich niewielka cześć zazwyczaj przewyższa to, co przekazują inne państwa ${ }^{26}$.

Niemieckie zaangażowanie $\mathrm{w}$ pomoc bilateralną i multilateralną wymagało utworzenia wewnątrz kraju szeregu rozwiązań, instytucji oraz uchwalenia wielu dokumentów, które umożliwiałyby i usprawniały taką działalność. Najważniejsza jest działalność dwóch ministerstw

\footnotetext{
${ }^{24}$ Ibidem, s. 92-95.

${ }^{25}$ Rozporządzenie Rady (WE) nr 1257/96 z dnia 20 czerwca 1996 roku dotyczące pomocy humanitarnej, Dz.U. L 163 z 2 lipca 1996; J. Dobrowolska-Nowak: op, cit., s. 52-53.

${ }^{26}$ ECHO: The European Community Humanitarian Office, "Humanitarian Aid from the European Community. Annual Report 1992", s. 8-12 oraz ECHO's partnership with non-governmental organizations, ibidem, s. 13.
} 
RFN: Ministerstwa Spraw Zagranicznych i Ministerstwa Współpracy Gospodarczej i Rozwoju, a także, choć w znacznie mniejszym stopniu, Ministerstwa Spraw Wewnętrznych, Ministerstwa Obrony Narodowej, Ministerstwa Zdrowia i Ministerstwa Komunikacji, Budownictwa i Spraw Mieszkaniowych. Ministerstwa Spraw Zagranicznych, a zwłaszcza jego departamentów: Departamentu Narodów Zjednoczonych, Departamentu Praw Człowieka i Pomocy Humanitarnej oraz Komitetu Koordynacyjnego ds. Pomocy Humanitarnej i Przedstawiciela Rządu ds. Praw Człowieka i Spraw Humanitarnych, które wspierają ludność podczas nagłych katastrof i kryzysów humanitarnych, służąc krótkotrwałą pomocą w przetrwaniu ludności podczas kryzysu. Natomiast Ministerstwo Współpracy Gospodarczej i Rozwoju podejmuje działania w drugiej fazie kryzysu, kiedy sytuacja na obszarze wymagającym pomocy zostanie opanowana, a jego działania ograniczają się do pomocy średnio- i długoterminowej, czyli pomocy rozwojowej. Ministerstwo Obrony Narodowej działa natomiast w regionach kryzysów humanitarnych wywołanych konfliktami zbrojnymi, przy czym regiony, dla których finansuje wsparcie, pokrywają się z obszarami stacjonowania lub aktywności żołnierzy zagranicznych misji Bundeswehry. Działania te są więc szczególnie widocznym przykładem podwójnego motywowania pomocy: humanitaryzmem i dążeniem do poprawy (przez zjednywanie ludności) warunków funkcjonowania i bezpieczeństwa własnych żołnierzy. W działalności związanej z pomocą rozwojową coraz większe znaczenie ma też działalność Urzędu Kredytowego ds. Odbudowy, Niemieckiej Fundacji Rozwoju Międzynarodowego, Niemieckiego Stowarzyszenia Rozwoju, Niemieckiego Instytutu Polityki Rozwojowej, Niemieckiej Służby Rozwoju oraz Niemieckiej Służby Wymiany Akademickiej ${ }^{27}$.

Od kilkunastu lat coraz większe znaczenie w udzielaniu pomocy, zwłaszcza humanitarnej, ale także rozwojowej, ma działalność organizacji pozarządowych. W Niemczech w tej sferze działa już ponad 200 instytucji i organizacji. Większość z nich ma charakter pozarządowy, co oznacza, że jest finansowana ze źródeł prywatnych. Znaczna ich liczba to lokalne oddziały różnych organizacji międzynarodowych. Prowadzona przez część z nich polityka bywa zupełnie inna niż polityka

${ }^{27}$ Bericht..., s. 32-36; J. Dobrowolska-Polak: op. cit., s. 17-26. 
rządu RFN. Wynika to z faktu, że instytucje i organizacje pozarządowe kierują się interesem politycznym i ekonomicznym tych grup społecznych, które je utworzyły i finansują ich działalność. Jednak część z nich jest wspomagana finansowo przez rząd niemiecki. Przekazując im pieniądze, często według klucza politycznego, czyni się je bezpośrednimi instrumentami realizacji polityki zagranicznej, utrzymując wrażenie ich czołowej roli w decydowaniu i przekazywaniu pomocy. Rząd używa organizacji do tworzenia pozytywnego wizerunku Niemiec, szczególnie w rejonie żywotnych interesów RFN. Zwłaszcza że to właśnie organizacje bardzo często działają w sferach „mniej efektownych” i przynoszących mniejsze korzyści. Najważniejsza rola przypada następującym organizacjom: Adventitische Entwicklung und Katastrophenhilfe, Arbeiter-Samariter-Bund, Ärzte der Welt, Ärzte ohne Grenzen, CARE Deutschland-Luksemburg, Deutscher Caritasverband, Deutsches Rotes Kreuz, Deutsche Welthungerhilfe, Deutsche Gesellschaft für Technische Zusammenarbeit, Deutsche Welthungerhilfe, Diakonie Katastrophenhilfe, Medico International, Hilfe zur Selbsthilfe, Care Germany, Johanniter International, Humedica Internationale Hilfe. Odrębną grupę stanowią związane z partiami politycznymi fundacje. Są one bardzo aktywnymi podmiotami działalności związanej z międzynarodową pomocą humanitarną i rozwojowa, jednak ich działalność jest bardzo upolityczniona. Najważniejsze z nich to: Fundacja im. Fryderyka Eberta, Fundacja im. Konrada Adenauera, Fundacja im. Fryderyka Naumanna, Fundacja im. Hansa Seidla. Rolę nie do przecenienia w niemieckiej pomocy mają też działania Kościołów katolickiego i ewangelickiego. Pod ich auspicjami utworzono instytucje i organizacje specjalizujące się $\mathrm{w}$ tego rodzaju działalności. Najważniejsze to katolickie „Miseror” i „Arbeitsgemeinschaft für Entwicklungshilfe“ oraz ewangelickie „Brot für Welt” i „Dienste in Übersee". Ważną rolę w organizacji pomocy rozwojowej odgrywają także niemieckie oddziały międzynarodowych chrześcijańskich organizacji charytatywnych, takich jak Międzynarodowa Chrześcijańska Służba Pokoju i Światowa Służba Pokoju ${ }^{28}$.

${ }^{28}$ NGOs and Humanitarian Organizations. Who Have Signed the Framework Partnership Contract, "Humanitarian Aid of the European Union. Annual Report 1993”, s. 32-33, 41; A. Nowak: op. cit., s. 75-80. 
Niemcy są jednym z nielicznych państw, które mają uchwalone szczegółowe przepisy dotyczące zasad udzielania pomocy. Jednak należy zauważyć, że nie zawsze są one przestrzegane. Dotyczy to zwłaszcza pomocy udzielanej w ramach konfliktu zbrojnego, np. wspomniany już Afganistan, katastrofa humanitarna podczas exodusu kosowskich Albańczyków. Najważniejsze znaczenie mają zasady niemieckiej pomocy humanitarnej (jest to w zasadzie Kodeks zachowań przyjęty w ramach Międzynarodowego Komitetu Czerwonego Krzyża, który został importowany na poziom wewnątrzniemiecki) oraz zestaw reguł obowiązujących niemiecką pomoc humanitarną.

Zasady niemieckiej pomocy humanitarnej sformułowane są następująco:

- Celem pomocy humanitarnej jest łagodzenie ludzkiego cierpienia.

- Wszyscy ludzie są uprawnieni do otrzymywania pomocy i ochrony humanitarnej; powinno być zagwarantowane prawo do przekazywania pomocy i ochrony humanitarnej.

- Pomoc i ochrona powinny być świadczone bez jakiejkolwiek dyskryminacji. Pomoc humanitarna nie może być uzależniona od wpływów politycznych ani religijnych.

- Organizacje pomocowe i instytucje rządowe powinny działać zgodnie z własnymi zasadami oraz ponosić odpowiedzialność za własne działania.

- Podczas przekazywania pomocy powinny szanować godność ludzką.

- Powinny dziś szanować prawa i zwyczaje państwa, na którego terytorium działają.

- Powinny wspierać się i współdziałać ze sobą tak dalece, jak to jest możliwe.

- Powinny być odpowiedzialne względem beneficjentów i donatorów.

- Pomoc humanitarna jest pierwszą i najważniejszą pomocą dla przetrwania ludzi. Musi zawierać środki samopomocy i redukować podatność na katastrofy.

- Organizacje pomocowe i instytucje rządowe powinny angażować lokalnych partnerów (lokalne NGOs i in.) na jak najwcześniejszym etapie pomocy. 
- Angażowani powinni być również beneficjenci pomocy.

- Pomoc humanitarna musi trafiać tam, gdzie jest potrzebna. Jedynym kryterium rozdziału pomocy muszą być potrzeby humanitarne. Pomoc najpierw powinna trafić do regionu dotkniętego kryzysem ${ }^{29}$.

Natomiast najważniejsze zasady zestawu reguł obowiązujących niemiecką pomoc humanitarną są następujące:

- działanie zgodnie $\mathrm{z}$ nakazem humanitaryzmu, udzielanie pomocy wszędzie, gdzie jest potrzebna, traktowanie pomocy jako obowiązku; „podstawową motywacją naszej odpowiedzialności na klęskę jest zmniejszenie ludzkiego cierpienia wśród najmniej zdolnych do wytrzymania napięcia wywołanego klęską [...] kiedy przekazujemy pomoc humanitarną nie jest to akt stronniczy ani polityczny i tak powinien być postrzegany;

- udzielanie pomocy bez jakichkolwiek dyskryminacji, wyłącznie na podstawie analizy podstawowych potrzeb, zgodnie z zasadą proporcjonalnego rozdziału zasobów; „implementacja tej uniwersalnej, bezstronnej i niezależnej polityki będzie efektywna tylko wtedy, jeśli my i nasi partnerzy będziemy mieli dostęp do zasobów koniecznych dla prowadzenia sprawiedliwej pomocy i jeśli będziemy mieli dostęp do wszystkich ofiar konfliktu;

- niewykorzystanie pomocy dla czyichś przyszłych politycznych lub religijnych korzyści; „pomoc powinna być niezależna od przestrzegania przez otrzymujących ją tych [politycznych i religijnych] opcji";

- niezależność i wolność od stania sie instrumentem polityki zagranicznej rządu oraz interesów innych donatorów; pomocą nie powinna kierować potrzeba pozbycia się przez donatora nadmiaru towaru ani polityczny interes żadnego z poszczególnych donatorów;

- poszanowanie kultury i zwyczajów obowiązujących w społeczeństwie i państwie w rejonie kryzysu;

- budowanie zdolności odpowiedzi na kryzys w oparciu o lokalne możliwości;

- włączanie do zarządzania rozdziałem pomocy humanitarnej beneficjentów, "powinniśmy zapewnić partycypacji całego społeczeństwa w naszej pomocy";

\footnotetext{
${ }^{29}$ J. Dobrowolska-Polak: op. cit., s. 28-29.
} 
- dążenie do redukcji przyszłej wrażliwości na klęski; „wszelkie akcje pomocowe mają wpływ na szansę powodzenia długoterminowego rozwoju”, "powinny minimalizować negatywny wpływ pomocy humanitarnej;

- odpowiedzialność wobec beneficjentów i donatorów; „działamy jako instytucjonalny łącznik partnerstwa pomiędzy tymi, którzy chcą pomagać i tymi, którzy potrzebują pomocy. [...] Całe nasze postępowanie [...] powinno odzwierciedlać postawę otwartości i przejrzystości. Uznajemy potrzebę sprawozdań z naszej działalności, zarówno z perspektywy efektywności, jak i obowiązek zapewniania stosownego monitoringu dystrybucji pomocy;

- poszanowanie dla ofiar konfliktu jako dla ludzi, a nie obiektów litości; „powinniśmy przedstawić obiektywny wizerunek sytuacji klęski, w którym są uwypuklone zdolności i aspiracje ofiar klęski, a nie tylko ich wrażliwość i strach ${ }^{30}$.

W efekcie stworzono jeden z najefektywniejszych systemów udzielania pomocy na świecie. Niemieckie instytucje są w stanie zareagować już w kilka godzin, co jest niezwykle rzadko spotykane, po nastąpieniu tragicznego wydarzenia, którego konsekwencje wymagają udzielania poszkodowanym pomocy. Szczególne znaczenie ma także włączenie się Niemiec już w latach sześćdziesiątych XX wieku w pomoc kadrową dla państw Trzeciego Świata. Braki kadrowe to jeden z największych problemów tych państw, będący konsekwencją okresu kolonialnego, kiedy to mocarstwa kolonialne ograniczały rozwój lokalnej inteligencji i kadr technicznych. Pomoc ta polegała i nadal polega na:

- organizacji i finansowaniu studiów i szkolenia zawodowego w RFN, kształcenie na miejscu;

- wysyłaniu nauczycieli do krajów Trzeciego Świata;

- pomocy finansowej i technicznej przy tworzeniu systemów szkolnictwa, oświaty i nauki w krajach Trzeciego Świata;

- finansowaniu szkolenia niemieckich specjalistów, którzy są zatrudniani i opłacani przez kraj rozwijający się, korzystający z ich usług (tzw. integrierte Fachkraefte).

\footnotetext{
${ }^{30}$ Bericht..., s. 14-16.; J. Dobrowolska-Polak: op. cit., s. 27-28.
} 
Upolitycznienie niemieckiej pomocy humanitarnej i rozwojowej nie powoduje, że traci ona na wartości. Sprawdzianem dla tych działań jest stosunek państw do tzw. kryzysów zapomnianych, czyli toczących się poza ważnymi obszarami, zarówno niemedialnych, długotrwałych konfliktów czy alarmujących problemów humanitarnych, takich jak np. niedożywienie dzieci, jak i małych klęsk żywiołowych bądź katastrof, które ze względu na swoją wielkość nie budzą zainteresowania mediów i światowej opinii publicznej. Są to sytuacje w których tylko nieliczni pomagają. Do tej grupy zaliczają się Niemcy, np. podczas powodzi w Peru w 2001 roku 100\% udzielonej wówczas pomocy pochodziło z RFN ${ }^{31}$. Niemcy podchodzą też elastycznie do wydarzeń na świecie - w miarę konieczności zwiększając, a nie przeszeregowując środki, co jest praktyką wielu państw, przeznaczone na pomoc. Jest to kolejny dowód na to, jakie znaczenie dla RFN ma udzielanie międzynarodowej pomocy humanitarnej i rozwojowej ${ }^{32}$.

Republika Federalna Niemiec jest jednym z głównych donatorów pomocy humanitarnej i rozwojowej na świecie. Wsparcie z Niemiec płynie zarówno dla ofiar klęsk i katastrof, konfliktów zbrojnych, jak i w sytuacjach konfliktów zapomnianych i alarmujących problemów humanitarnych. Niemcy reagują niespotykanie szybko (często w ciągu kilku godzin od wystąpienia zdarzenia) na apele o pomoc. Jest to możliwe dzięki utworzeniu bardzo sprawnego systemu wewnątrz kraju obejmującego instytucje publiczne, organizacje pozarządowe i szereg dokumentów regulujących tego typu działalność. Najważniejsze znaczenie mają decyzje i działania podejmowane przez Ministerstwo Spraw Zagranicznych (pomoc humanitarna) i Ministerstwo Współpracy Gospodarczej i Rozwoju (pomoc rozwojowa), a także Ministerstwo Spraw Wewnętrznych, Ministerstwo Obrony Narodowej, Ministerstwo Zdrowia i Ministerstwo Komunikacji, Budownictwa i Spraw Mieszkaniowych. Ważnym donatorami jest też ponad 200 organizacji pozarządowych,

\footnotetext{
${ }^{31}$ Ibidem, s. 57.

${ }^{32}$ J. Dobrowolska-Nowak: op. cit., s. 66.
} 
które podejmują działania w najtrudniejszych dziedzinach związanych z pomocą międzynarodową.

Podejmując działania w zakresie pomocy międzynarodowej, donatorzy powinni kierować się Regułami Dobrego Świadczenia Pomocy Humanitarnej - humanitaryzmem, bezstronnością, niezależnościa, neutralnością, szybkościa, adekwatnością możliwie niskimi kosztami administracyjnymi, które Niemcy dodatkowo wpisali w swoich wewnętrznych dokumentach: Zasadach niemieckiej pomocy humanitarnej oraz Zestawie reguł obowiązujących niemiecką pomoc humanitarną. Praktyka pokazuje jednak, że ważniejsze od chęci pomocy i solidarności z potrzebującymi bywają interesy polityczne i ekonomiczne. Widać to szczególnie wyraźnie na przykładzie niemieckiej pomocy dla ofiar konfliktów zbrojnych, obecnie zwłaszcza w Afganistanie, gdzie pomoc udzielana jest, aby wzmocnić bezpieczeństwo niemieckich żołnierzy. RFN od początku liczyła, że bycie jednym z najhojniejszych donatorów na świecie pozwoli budować jej korzystny wizerunek na arenie międzynarodowej i zyskać kolejny argument w budowaniu swojej pozycji $\mathrm{w}$ relacjach międzypaństwowych i na arenach organizacji międzynarodowych, uzyskać wpływ na kształtowanie określonego światopoglądu, postaw społecznych, obyczajowych i politycznych u społeczeństw państw-biorców pomocy, osiągać konkretne korzyści finansowe i rynki zbytu. Dlatego RFN niechętnie rezygnuje z możliwości decydowania, komu i w jaki sposób należy pomóc. W praktyce oznacza to skupienie się na pomocy bilateralnej, przy mniejszym zaangażowaniu się $\mathrm{w}$ pomoc wielostronną udzielaną przez takie organizacje jak ONZ, UE oraz mniejsze wsparcie dla międzynarodowych organizacji pozarządowych i ich lokalnych przedstawicielstw. Tymczasem to właśnie pomoc wielostronna ma największą wartość, jest bowiem często najskuteczniejsza i nie uzależnia biorców od donatorów $\mathrm{w}$ takim stopniu jak pomoc dwustronna. Często instrumentalnie traktowane są też organizacje pozarządowe, będące donatorami pomocy. Rząd RFN wspiera te, które realizują programy ważne z punktu widzenia niemieckiej polityki zagranicznej. Podwójne motywowanie udzielanej pomocy i budowa własnej pozycji w związku z taką działalnością nie powoduje jednak, że pomoc ta przestaje być cenna. Potrzeby są tak duże, że liczy się każda pomoc. 


\section{Abstract \\ International humanitarian and development aid as the instruments of German foreign politics}

As far as both humanitarian and development aid are concerned, Germany is a major donor. Involvement in such activity is aimed most of all at building up Germany's strong position in the international arena, creating a positive image of Germany's presence abroad, gaining in influence on the formation of a specific world view and of attitudes in the social, political and moral spheres in the recipient countries, and obtaining tangible financial, political and economic benefits. Support from Germany flows to victims of disasters and catastrophes, forgotten armed conflicts and alarming humanitarian problems. To any appeals for assistance, Germany reacts extremely fast. This is possible because of a very efficient system established in the country, comprised of public institutions and non-governmental organisation and with its operations in the international arena regulated in a series of documents. What is characteristic of German aid is the speed with which at arrives to the aggrieved, its adequacy and its subordination to political objectives, particularly in cases of providing aid in armed conflict situations. The fact that Germany is involved, most of all, in bilateral aid operations, which makes it possible to make decisions on her own as to whom to provide with assistance and how, and where, and that, moreover, such assistance is not anonymous, as is the case with the multilateral aid provided by international organisation, which is both more efficient and preferred by its recipients, is evidence of such policy. 